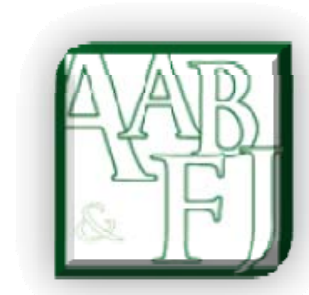

\title{
An Empirical Investigation of the Ohlson Model-A Panel Cointegration Approach
}

\author{
Shih-Cheng Lee ${ }^{1}$, Jiun-Lin Chen², Ming-Shann Tsai ${ }^{3}$
}

\begin{abstract}
This paper uses a panel cointegration method to test the Ohlson (1995) model. Sample firms are selected from US listed companies during the period from 1986 to 2004 . The analysis is focussed on whether the fundamental value of corporations cointegrates with market value. The results support the hypothesis of cointegration that a long-run equilibrium relationship exists between a corporation's fundamental value and market value. Subsequently, this paper evaluates the predictive power of the Ohlson model for future market value assessment. Since the Ohlson model is built upon the dividend discount model, this paper also examines the validity and the predictive power of the dividend discount model as a basis for comparison. The results show that the Ohlson model can forecast future stock price movements much more accurately in any predicted horizon.
\end{abstract}

Keywords: Ohlson model; dividend discount model; panel cointegration; Theil's U statistic

JEL Classification: G17

\footnotetext{
${ }^{1}$ Faculty of Finance, Yuan Ze University, Taiwan; School of Accounting and Finance, University of Adelaide

${ }^{2}$ School of Accounting and Finance, University of Adelaide (corresponding author: alex.chen@adelaide.edu.au)

${ }^{3}$ Department of Finance, National University of Kaohsiung, Taiwan
} 


\section{Introduction}

Ohlson's (1995) equity valuation model has been studied extensively because of its significance in the assessment of stock price over a prolonged period and the prediction of future stock price. Current literature on the investigation of the Ohlson model is dominated by the cross-sectional and time-series approaches. Traditionally, most researchers have employed the cross-sectional approach to study the Ohlson model. Since the cross-sectional analysis places emphasis on the fundamental values that track simultaneously the stock prices and returns, this method enjoys popularity among many researchers (Abarbanell \& Bernard 2000; Dechow, Hutton \& Sloan1999; Francis, Olsson \& Oswald 2000; Frankel \& Lee 1998; Penman \& Sougiannis 1998). However, the main practical limitation in the cross-sectional approach is the time-series nature of the Ohlson model ${ }^{4}$.

Alternatively, many of the recent empirical studies on the Ohlson model have moved away from the cross-sectional approach and adopted the time-series approach to explain the relationship among share prices, returns and future returns. These include the studies by Ahmed, Morton and Schaefer (2000); Ballester, Livnat and Sinha (2002); Callen and Morel (2000); Lee, Myers and Swaminathan (1999); Morel (1999, 2003) and Myers (1999). The time series approach focuses on the time-series relation between earnings, book values and other value-relevant variables. Nevertheless, this approach has unique research design issues that can potentially be critical in nature. Granger and Newbold (1974) and Phillips (1986) have shown that ordinary least squares (OLS) regressions with nonstationary time-series data can generally lead to spurious results mistakenly. Other studies have offered empirical evidence that indicate the tendency for economic and accounting variables such as market value and book value to exhibit nonstationary behavior (Callen \& Morel 2005; Fama \& French 1992; Qi, Wu \& Xiang 2000; Wu, Kao \& Lee 1996).

While the OLS regression is attractive in the investigation of the Ohlson model and other derived hypotheses, the verification of the cointegration of accounting variables with market value of common equity becomes an essential step. Otherwise, the resulting OLS estimates may be difficult to interpret and can be misleading. Cointegration refers to circumstances when nonstationary dependent variables and regressors are interconnected through a long-run equilibrium relationship. Although the Ohlson model didn't consider the nonstationarity of market value, book value, and residual income, the market value can still relate to book value and residual income through cointegration. If equity valuation models are valid representations of the long-run stock price behaviour, the share prices will then deviate from its equity fundamentals only in the short-run.

Qi et al. (2000) apply the unit root test of Phillips and Perron (1988) to investigate the stationarity of three key variables in the Ohlson model and examine the cointegration among these key variables using the Engle and Granger (1987) test. Their sample consists of ninetyfive US firms with complete data range over a period of almost forty years (1958-1994). They can not reject the null hypothesis that market value and book value are nonstationary for most of the sample firms. In addition, they report the non-cointegration of book value and residual income with market value for 80 percent of the sample firms. The existence of nonstationarity in economic and accounting time series implies that tests of cointegration between economic and accounting variables are necessary in a more realistic modeling of the stock behavior. There is a considerable incentive to study the long-run equilibrium

\footnotetext{
${ }^{4}$ Lo and Lys (2000) point out that, to estimate the Ohlson model cross-sectionally, one needs to convert the model for multiple firms. They argue that levels regressions are likely to result in biased coefficient estimates and $R^{2}$ values due to omission of a scale factor.
} 
relationship between stock price and the fundamental value of corporations in Ohlson accounting-based equity valuation model.

Although both time-series and cross-section approaches are popular methodologies, both possess a number of drawbacks. On one hand, the cross-section methods are subjected to heteroscedasticity problems and can often fail to detect the dynamic factors that may affect the dependent variables. On the other hand, the time-series methods are subjected to autocorrelation and multicollinearity problems. Karathanassis (2003) employs a combination of time-series and cross-section data (panel data analysis) to compare the explanatory power of the Ohlson model with that of the traditional valuation models in the Athens Stock Exchange for the period between 1993 and 1998. He employs the Error Components Model, which indicates the similarity between the Ohlson model and the traditional models. The panel data analysis has many advantages, which includes its rendering of efficient and unbiased estimators, larger number of degrees of freedom available for estimation, and means to overcome the restrictive assumptions of the linear regression model. Therefore, the objective of this paper is aimed at an improved understanding of the long-run equilibrium relationship between stock price and accounting variables according to the Ohlson model through the panel cointegration tests.

This paper has five sections. Section 1 introduces the significance of the current study within the scope of accounting-based equity valuation model. Section 2 presents the economic specification and panel cointegration test of research design. Section 3 reports and discusses the sample selection as well as its variable measurement. Section 4 reports results of panel cointegration test and panel prediction analysis. Some concluding remarks are given in Section 5.

\section{Background and Research Design}

\subsection{The Ohlson Model}

The underlying mathematics of the Ohlson model has been described extensively in the literature. A satisfactory Ohlson model fulfills the dividend discount model (DDM), the clean surplus accounting relationship (CSR), and the linear information dynamics (LID). A linear closed form valuation equation, based on these three fundamental assumptions, renders a market value, which equals to a book value plus a linear function of current abnormal earnings. The residual income valuation model is the theoretical foundation for the price and return regressions empirically implemented in this section.

The first assumption is the fulfillment of the DDM, which means that the market value of the common equity equals to the present value of expected future dividends. This is a standard consideration as in most standard neoclassical models of security valuation. Ohlson assumes that investors have characteristics of risk neutrality and homogenous belief and that interest rates satisfy a flat term structure. The first assumption is expressed by:

$$
V_{t}=\sum_{\tau=1}^{\infty} R_{f}^{-\tau} E_{t}\left(d_{t+\tau}\right)
$$

where,

$V_{t}=$ the market value, or price, of the firm's equity at date $t$.

$d_{t}=$ net dividends paid at date $t$.

$R_{f}=$ the risk-free interest rate plus one.

$E_{t}=$ the expected value operator conditioned on the date $t$ information. 
The second assumption is the fulfillment of the CSR relation. The clean surplus relation requires the satisfaction of two conditions: (i) the change in book values between two dates equals to the earnings minus dividends, imposing the clean surplus relation; and (ii) dividends reduce current book value, but not current earnings. The following mathematical restrictions are applied for this relationship:

$$
B V_{t}=B V_{t-1}+N I_{t}-d_{t}
$$

where,

$B V_{t}=$ (net) book value at date $t$.

$N I_{t}=$ earnings for the period from time $t-1$ to $t$.

and

$$
\begin{aligned}
& \partial B V_{t} / \partial d_{t}=-1 \\
& \partial N I_{t} / \partial d_{t}=0
\end{aligned}
$$

Ohlson then defines the residual income (RI), or abnormal earnings, as current accounting earnings minus a charge for the use of capital as measured by the beginning book value multiplied by the cost of capital.

$$
R I_{t}=N I_{t}-\left(R_{f}-1\right) B V_{t-1}
$$

Combining equations (2-2) and (2-3) give,

$$
d_{t}=R I_{t}-B V_{t}+R_{f} B V_{t-1}
$$

Then, substitute equation (2-4) into equation (2-1) to generate the equation below:

$$
V_{t}=B V_{t}+\sum_{\tau=1}^{\infty} R_{f}^{-\tau} E_{t}\left(R I_{t+\tau}\right)
$$

The above equation redefines the original DDM formula of equation (2-1) in terms of book value and the present value of anticipated residual income. This relationship is then referred to as the residual income valuation model (RIM). In other words, the firm's future profitability as measured by the present value of the anticipated abnormal earnings sequence reconciles the difference between market and book values.

The third assumption is the fulfillment of the LID, which describes the stochastic timeseries behavior of abnormal earnings. LID means that residual income and other information satisfy the stochastic and autoregressive process. The final assumption is expressed by:

$$
\begin{aligned}
R I_{t+1} & =\omega R I_{t}+v_{t}+\varepsilon_{1 t+1} \\
v_{t+1} & =\quad \mathcal{V}_{t}+\varepsilon_{2 t+1}
\end{aligned}
$$

where,

$v_{\mathrm{t}}=$ information other than residual income.

$\varepsilon_{1 t+1}, \varepsilon_{2 t+1}=$ unpredictable, mean-zero disturbance terms (independent and identically distributed).

$\omega, \gamma=$ fixed persistence parameters that are non-negative and less than 1 .

Collectively, the three basic assumptions (DDM, CSR, and LID) allow the derivation of the linear valuation equation as follows:

$$
V_{t}=B V_{t}+\alpha_{1} R I_{t}+\alpha_{2} v_{t}
$$

where,

$$
\begin{aligned}
& \alpha_{1}=\omega /\left(R_{f}-\omega\right) \geq 0 \\
& \alpha_{2}=R_{f} /\left(R_{f}-\omega\right)\left(R_{f}-\gamma\right) \geq 0
\end{aligned}
$$


The dependency of the market value on the book value is illustrated in equation (2-8), where the book value is adjusted accordingly for (i) the current profitability as measures by the abnormal earnings, and (ii) other information that modifies the prediction of future profitability. Ohlson points out that the two dynamic equations combine with the clean surplus relation to ensure that all value-relevant events will be absorbed by current or subsequent periods' earnings and book values. Additionally, the three assumptions lead to a linear, closed-form, valuation solution explaining goodwill, that is, market value of firm is equal to book value plus a linear function of current residual income and the scalar variable representing other information. In this paper, this paper does not consider the valuation factor of other information.

\subsection{A Panel Cointegration Test}

Our econometric analysis centers on panel estimation of the short-horizon predictive regression,

where,

$$
\begin{gathered}
\Delta P_{i t+1}=\beta x_{i t}+e_{i t+1} \\
e_{i t+1}=\gamma_{i}+\theta_{\mathrm{t}+1}+u_{i t+1}
\end{gathered}
$$

$x_{i t}=V_{i t}-P_{i t}$ is the deviation of the stock price from its fundamental value.

$V_{i t}=$ the firm's theoretical value.

$P_{i t}=$ the firm's market value.

We give the regression error $e_{i t+1}$ an unobserved component interpretation, where $\gamma_{i}$ is an individual-specific effect, $\theta_{t}$ is a time-specific effect that allows us to account for a limited amount of cross-sectional dependence, and $u_{i t+1}$ is the residual idiosyncratic error.

Equation (2-9) is the panel version of the short-horizon predictive regression studied by Fama and French (1988), Campbell and Shiller (1988), and Hodrick (1992) in a study of stock returns; also by Berben and van Dijk (1998) in connection with exchange rates. In the single equation context, the predictive regression is the linear least squares projection of the stock price return on the deviation of the stock price from its fundamental value so that $e_{t}$ is uncorrelated with $x_{t}$ by construction. The slope coefficient is an estimate of $\operatorname{Cov}\left(x_{t}, \Delta M V_{t+1}\right) / \operatorname{Var}\left(x_{t}\right)$, which does not disentangle contributions from short-run and long-run dynamics.

In the single-equation case, Berben and van Dijk (1998) build on Hansen (1995) to show that the predictive regression can be estimated regardless whether $x_{t}$ is $\mathrm{I}(0)$ or $\mathrm{I}(1)$. They show $\beta=0$ is a test of the hypothesis that the nominal exchange rate and the monetary fundamental value are not cointegrated under the null hypothesis $x_{t}$ is $\mathrm{I}(0)$. Mark and Sul (2001) extend this line of argument to panel data and take the null hypothesis that $x_{i t}$ is nonstationary for all $i=1, \ldots, N$. We establish our model according to Mark and Sul (2001). Since $\Delta P_{i t+1}$ is stationary and $x_{i t}$ is nonstationary, they are asymptotically independent and the true value of $\beta$ coefficient is zero under the null hypothesis. Let $\Delta \underline{P}_{i}=\left(\Delta P_{1 i}, \Delta P_{2 i}, \ldots, \Delta P_{T i}\right)^{\prime}$, and $\Delta \underline{P}=\left(\Delta P_{1}, \Delta P_{2}, \ldots, \Delta P_{N}\right)^{\prime}$ be the vectorization of the observations on stock price returns, $\underline{x}_{i}=\left(x_{1 i}, x_{2 i}, \ldots, x_{T-1 i}\right)^{\prime}$ be the $T-1 \times 1$ vector of 
observations on $x_{i t}$ for industry $i, \underline{0}$ be a $T-1 \times 1$ vector of zeros, $\underline{\underline{l}}$ be a $T-1 \times 1$ dimensional identity matrix, and

$$
X=\left[\begin{array}{llllll}
\underline{x}_{1} & \mathrm{I} & \underline{0} & \underline{0} & \cdots & \underline{0} \\
\underline{x}_{2} & \mathrm{I} & \underline{\underline{l}} & \underline{0} & \cdots & \underline{0} \\
\underline{x}_{3} & \mathrm{I} & \underline{0} & \underline{\imath} & \cdots & \underline{0} \\
\vdots & & & & & \vdots \\
\underline{x}_{N} & \mathrm{I} & \underline{0} & \underline{0} & \cdots & \underline{\imath}
\end{array}\right]
$$

The least-squares dummy variable estimator (LSDV) of $\beta$ coefficient is obtained by running OLS on the pooled observations, $\beta_{l s d v}=\left(\mathrm{X}^{\prime} \mathrm{X}\right)^{-1} \mathrm{X}^{\prime}(\Delta \underline{P})$. Under the null hypothesis that $x_{i t}$ is $\mathrm{I}(1), \beta_{\text {lsdv }} \stackrel{\rho}{\longrightarrow} 0$ so that the LSDV estimator is a consistent estimator of the true value of $\beta=0$. However, the panel regression is affected by the second order asymptotic bias that causes $\sqrt{N} T \beta_{l s d v}$ to diverge. Since both $\beta_{l s d v}$ and its t-ratio do not have a well defined asymptotic distribution, the construction of appropriate t-tests for the testing of hypotheses regarding the slope coefficient is not possible.

To control for this asymptotic bias, Mark and Sul (2001) employ the panel dynamic OLS estimator. In the panel dynamic OLS, the current value and $\rho_{i}$ leads and lags of $\Delta x_{i t-1}$ are included in the equation for industry $i$. The estimation of the system is given by equation $(2-11)$,

$$
\begin{aligned}
& \Delta P_{i t}=\gamma_{i}+\theta_{t}+\beta x_{i, t-1}+\sum_{j=-\rho_{i}}^{\rho_{i}} \delta_{i j} \Delta x_{i, t-j-1}+u_{i t}, \\
& i=1, \ldots, N, t=\rho_{i}+2, \ldots, T-\rho_{i}+1 \text {. Let } \bar{\rho} \quad \text { be the largest } \rho_{i} \text { and let } \\
& \underline{Z}_{i t}=\left(\Delta x_{i t+\rho_{i}-1}, \ldots, \Delta x_{i t-\rho_{i}-1}\right), Z_{i}=\left(\underline{Z}_{1 i}, \ldots, \underline{Z}_{T i}\right)^{\prime}, \text { and } \\
& \widetilde{\mathrm{X}}=\left[\begin{array}{cccccccccccc}
\underline{x}_{1} & \mathrm{Z}_{1} & 0 & 0 & \cdots & 0 & \mathrm{I} & \underline{0} & \underline{0} & \cdots & \underline{0} & \underline{0} \\
\underline{x}_{2} & 0 & \mathrm{Z}_{2} & 0 & & 0 & \mathrm{I} & \underline{l} & \underline{0} & \cdots & \underline{0} & \underline{0} \\
\underline{x}_{3} & 0 & 0 & \mathrm{Z}_{3} & & 0 & \mathrm{I} & \underline{0} & \underline{\imath} & \cdots & \underline{0} & \underline{0} \\
\vdots & & & & & \vdots & \vdots & & & & & \vdots \\
\underline{x}_{N} & 0 & \cdots & 0 & \cdots & \mathrm{Z}_{\mathrm{N}} & \mathrm{I} & \underline{0} & \underline{0} & \cdots & \underline{0} & \underline{\imath}
\end{array}\right]
\end{aligned}
$$

Then, the panel dynamic OLS estimator of $\beta$ is the first element of the vector $\left(\widetilde{\mathrm{X}}^{\prime} \tilde{\mathrm{X}}\right)^{-1} \widetilde{\mathrm{X}}^{\prime}(\Delta \underline{P})$. Mark and Sul (1999) show that,

$$
\sqrt{N} T\left(\beta_{\text {pdols }}-\beta\right) N(\underline{0}, 2 \widetilde{\mathrm{V}})
$$

as $T \rightarrow \infty, N \rightarrow \infty$ where $\tilde{\mathrm{V}}$ is consistently estimated by $\widetilde{\mathrm{V}}_{N T}=\widetilde{\mathrm{B}}_{N T}^{-1} \widetilde{\mathrm{A}}_{N T} \widetilde{\mathrm{B}}_{N T}^{-1}$; $\widetilde{\mathrm{B}}_{N T}=\left(1 / N T^{2}\right) \sum_{i=1}^{N} \sum_{t=1}^{T} \widetilde{x}_{i t-1} \widetilde{x}_{i t-1}^{\prime} ; \widetilde{\mathrm{A}}_{N T}=\left(1 / N T^{2}\right) \sum_{i=1}^{N} \hat{\Omega}_{i}^{2} \sum_{t=1}^{T} \widetilde{x}_{i t-1} \widetilde{x}_{i t-1}^{\prime}$ and $\hat{\Omega}_{i}^{2}$ estimate the long run variance of $u_{i t}$.

Mark and Sul (2001) report that the asymptotic distribution of $\hat{\beta}_{\text {pdols }}$ is reasonably accurate for their Monte Carlo experiments. Since there is no guarantee that this is true for all regions of the parameter space, they supplement the asymptotic analysis by drawing inference from the bootstrap. The data generating process (DGP) underlying the bootstrap is the restricted vector autoregression, 


$$
\begin{aligned}
& \Delta P_{i t}=\mu_{s}^{i}+\varepsilon_{s t}^{i} \\
& \Delta x_{i t}=\mu_{x}^{i}+\sum_{j=1}^{k_{i}} a_{21 . j}^{i} \Delta P_{i t-j}+\sum_{j=1}^{k_{i}} a_{22, j}^{i} \Delta x_{i t-j}+\varepsilon_{x t}^{i}
\end{aligned}
$$

which imposes the null hypothesis that the stock price return is unpredictable and that $x_{i t}$ is nonstationary. The lag length in the $\Delta x_{i t}$ equations is determined by the Campbell-Perron rule on lagged $\Delta x_{i t}$ variables from an initial OLS regression. After determining the lag length, the equations for $\Delta x_{i t}$ are fitted by iterating the seemingly unrelated regression (SUR).

Let $\underline{\varepsilon}_{t}=\left(\varepsilon_{M V t}^{1}, \ldots, \varepsilon_{M V t}^{N}, \varepsilon_{x t}^{1}, \ldots, \varepsilon_{x t}^{N}\right)^{\prime}$ be the $(2 N \times 1)$ error vector. According to Mark and Sul (2001), we construct a nonparametric bootstrap by re-sampling the residual vectors $\left\{\hat{\varepsilon}_{1}, \hat{\varepsilon}_{2}, \ldots, \hat{\varepsilon}_{T}\right\}$ with replacement and build up the bootstrap observations of $P_{i t}$ and $x_{i t}$ recursively according to the estimated version of equation (2-13). Note that this re-sampling scheme preserves the cross-sectional dependence exhibited in the estimated residuals. The start-up values for $\Delta P_{i t}$ and $\Delta x_{i t}$ are obtained by direct block re-sampling of the data. Then, we apply the estimation procedure outlined above of $\beta_{\text {pdols }}$ and its asymptotic $t$-ratio to the bootstrapped data. After iterating 2000 times, the resulting $2000 t$-ratios form the bootstrap distribution.

\subsection{Measurement of Out-of-Sample Predictions}

A more precise breakdown of the objectives includes the examination of the cointegration of stock prices with long-run determinants as predicted by equity valuation models and examines the ability of equity fundamental value to forecast future stock price movements. The aspect of the prediction issue is studied by conducting an out-of-sample forecast experiment using the panel regression under the assumption of the cointegration of stock price and the accounting variables. Since the Ohlson model is built upon the DDM, it imposes further restrictions in relation to the DDM. The presumption must be that the Ohlson model will have better asymptotic prediction performance if the additional restrictions are correct, and will have worse prediction performance if they are inaccurate. This paper also examines validity and the predictive power of DDM as a basis for comparison. We compare predictions of the Ohlson model and DDM to those of the standard benchmark forecast implied by the random walk model.

Theil's $U$ statistic represents a comparison of the size of the projection errors that result from two different forecasting methods. This statistic is used to compare the errors as provide by the Ohlson model (or DDM) and the random walk model. Since each set of errors generates a root-mean-square prediction error (RMSPE), the ratios of the RMSPE from two competing models give rise to a Theil's $U$ statistic. These ratios allow the assessment of forecast precision and accuracy, which vary inversely to its predictive power. The higher the ratio of $U$-statistic represents the lower the accuracy of forecast. If the value of Theil's $U$ statistic is lower than one, the Ohlson model (or DDM) provides more accurate forecasts than the random walk model. If the Theil's $U$ statistic is equal or close to one, the two forecasting methods perform similarly (in terms of RMSE). If the value of Theil's $U$ statistic is higher than one, the Ohlson model (or DDM) provides less accurate forecasts than the random walk models. 


$$
\begin{gathered}
R M S P E_{m, h}=\left[\frac{\sum_{s=1}^{S}\left(F_{m, h, s}-P_{h, s}\right)^{2}}{S}\right]^{\frac{1}{2}} \\
\text { Theil's } U=\frac{R M S P E(\text { model })}{R M S P E(\text { random walk })}
\end{gathered}
$$

where $\mathrm{m}$ is the forecasting method; $\mathrm{h}$ is the horizon being forecast; $\mathrm{s}$ is the series being forecast; $\mathrm{S}$ is the number of series being summarized; $\mathrm{F}$ is the forecast value for the stock price; and $\mathrm{P}$ is the market value.

\section{Sample Selection and Variable Measurement}

Sample firms were selected from US listed firms on Compustat and CRSP database while regulated financial institutions and firms with negative book value were not considered for selection. A total of 458 firms were initially identified between 1986 and 2004. The data requirements include market value of common equity, book value of common equity, common dividends, total number of shares outstanding, income before extraordinary items, as well as firm's daily returns and market returns. Seventy-eight firms with missing data were removed from selection, yielding 380 firms.

Our sample period is determined based on the latest available data in our institution. Due to data limitation, the sample cannot be updated. Although our findings are based on the sample period between 1986 and 2004, our results are still applicable to the current market. Since our sample captures the whole economic cycle (both progression and recession periods), it enhances the ability of the model to predict future stocks value. Due to the data limitation, we only focus on the US market, without the cross-country analysis. Table 1 reports the sample distribution by industry. According to the first two-digit SIC code, our sample firms are classified into three industry groupings: (i) miscellaneous industries $(\mathrm{N}=60)$, (ii) manufacturing and mineral industries $(\mathrm{N}=228)$, (iii) transportation, communications, and utilities $(\mathrm{N}=92)^{5}$.

The fiscal year-end market value of common equity $\left(P_{t}\right)$, the fiscal year-end book value of equity $\left(B V_{t}\right)$, and the residual income for each firm in year $t\left(R I_{t}\right)$ are the three main variables in the Ohlson model. In this paper all financial variables are reported on a per share basis. The residual income for each firm in year $t\left(R I_{t}\right)$ is defined by equation (3-1):

$$
R I_{t}=N I_{t}-r_{t} B V_{t-1}
$$

Where $N I_{t}$ is the net income before extraordinary items for each firm at the end of fiscal year $t$, and $r_{t}$ is the cost of capital for each firm in year $t$. The role of $r_{t}$ should be, in theory, firmspecific, reflecting the premium demanded by equity investors to invest in a firm or project of comparable risk. However, in practice, there is little consensus on how this discount rate should be determined. For simplicity, we use commercial papers as proxy of variable of discount rate.

\footnotetext{
${ }^{5}$ Chava and Jarrow (2004) used this industry classification.
} 
The dividend discount model shows that the present value of the share should be equal to the dividend stream discounted by the return earned on securities of comparable risk. The dividends per share $\left(d_{t}\right)$ are then defined as the cash dividends per share for which the exdividend dates occur during the reporting year, adjusted for all stock splits and stock dividends that have occurred during the period. All the dividend information comes from Compustat database.

Table 1

Distribution by Industry Classification

\begin{tabular}{cll}
\hline Industry Code & SIC Code & Industry Name \\
\hline 1 & $<1000$ & Agriculture, Forestry and Fisheries \\
2 & $1000 \sim 1499$ & Mineral Industries \\
3 & $1500 \sim 1799$ & Construction Industries \\
4 & $2000 \sim 3999$ & Manufacturing \\
5 & $4000 \sim 4999$ & Transportation, Communications, and Utilities \\
6 & $5000 \sim 5199$ & Wholesale Trade \\
7 & $5200 \sim 5999$ & Retail Trade \\
8 & $7000 \sim 8899$ & Service Industries \\
9 & $9100 \sim 9999$ & Public Administration \\
\hline
\end{tabular}

Industry Variable

\begin{tabular}{lll}
1 & Miscellaneous Industries & (Industry Code $=1,3,6,7,9)$ \\
2 & Manufacturing and Mineral Industries & (Industry Code=2,4) \\
3 & Transportation, Communications, and Utilities & (Industry Code=5) \\
\hline
\end{tabular}

\section{Results and Discussion}

\subsection{Descriptive Statistics}

The descriptive statistics of all sample are organized according to different periods in Table 2: all periods (panel A), 1986 (panel B) and 2004 (panel C). The median values of all variables are smaller than its mean values in panel $A$, which illustrates the positive skewness of all variables. Table 3 presents the Pearson (panel A) and Spearman (panel B) correlation coefficients, which assess the relationship between two variables. However, some of the variables in this paper could be non-stationary and two non-stationary variables could essentially show correlations which are meaningless.

\subsection{Tests for Panel Cointegration of Models}

We consider three alternative industries. The three industries are (i) miscellaneous industries; (ii) manufacturing and mineral industries; and (iii) transportation, communications, and utilities. We employ least-squares dummy variable (LSDV) test and Mark and Sul (2001) 
panel cointegrating test; and the results of the panel test for cointegration are reported in Table 4.

In Table 4, Panel A and B present the results of LSDV test and Mark and Sul (2001) panel cointegration test, respectively. Under the LSDV test, we find that the null hypothesis of no cointegration is not rejected by all of the three industries at $\alpha=0.05$ in the dividend discount model and in the Ohlson (1995) model. Under the Mark and Sul (2001) panel cointegration test, the findings presented in the dividend discount model show that the null hypothesis of no cointegration is rejected by all of the three industries at $\alpha=0.05$. These results imply that the existence of a long-run equilibrium relationship between stock price and dividend. Meanwhile, the findings presented in the Ohlson (1995) model also showed that the null hypothesis of no cointegration is rejected by all of the three industries at $\alpha=0.05$. This result implies that the book values of equity and residual income are important variables for the understanding of stock price in the long run.

In summary, under the Mark and Sul (2001) panel cointegration test, we reject the hypothesis of no cointegration between the stock price and dividend. We also reject the hypothesis of no cointegration between the stock price and key accounting variables in the Ohlson (1995) model. The strength of the evidence for the dividend discount model and the Ohlson (1995) model is roughly equivalent. 
Table 2

Descriptive Statistics of the Sample

\begin{tabular}{lrrrrr}
\hline \multicolumn{7}{l}{ Panel A. Descriptive statistics in all variables } & & & \\
& Mean & Std. Dev & Q1 & Median & Q3 \\
\hline$P_{t}$ & 22.984 & 29.699 & 10.835 & 18.313 & 28.500 \\
$B V_{t}$ & 11.581 & 14.039 & 5.045 & 9.114 & 14.820 \\
$N I_{t}$ & 1.294 & 2.488 & 0.520 & 1.078 & 1.788 \\
$R I_{t}$ & 0.767 & 2.258 & 0.251 & 0.663 & 1.218 \\
$R I F_{t}$ & 0.278 & 3.650 & -0.309 & 0.271 & 0.982 \\
$r_{t}$ & 0.099 & 0.765 & 0.023 & 0.097 & 0.172 \\
$d_{t}$ & 0.644 & 0.618 & 0.207 & 0.492 & 0.886 \\
M/B ratio & 2.574 & 3.220 & 1.386 & 1.895 & 2.889 \\
\hline
\end{tabular}

Panel B. Descriptive statistics in 1986

\begin{tabular}{lrrrrr} 
& Mean & Std. Dev & Q1 & Median & Q3 \\
\hline$P_{t}$ & 12.221 & 11.329 & 5.054 & 10.250 & 16.333 \\
$B V_{t}$ & 7.506 & 7.510 & 2.401 & 5.231 & 10.131 \\
$N I_{t}$ & 0.773 & 1.173 & 0.276 & 0.629 & 1.117 \\
$R I_{t}$ & 0.429 & 1.082 & 0.154 & 0.409 & 0.764 \\
$R I F_{t}$ & -0.022 & 3.157 & -0.151 & 0.070 & 0.229 \\
$d_{t}$ & 0.476 & 0.566 & 0.100 & 0.273 & 0.600 \\
M/B ratio & 2.134 & 1.347 & 1.363 & 1.688 & 2.477 \\
\hline
\end{tabular}

Panel C. Descriptive statistics in 2004

\begin{tabular}{lrrrrr} 
& Mean & Std. Dev & Q1 & Median & Q3 \\
\hline$P_{t}$ & 39.406 & 55.025 & 22.710 & 32.060 & 46.310 \\
$B V_{t}$ & 17.593 & 21.326 & 9.602 & 14.323 & 21.208 \\
$N I_{t}$ & 2.064 & 2.533 & 0.939 & 1.645 & 2.548 \\
$R I_{t}$ & 1.295 & 2.147 & 0.392 & 1.007 & 1.834 \\
$R I F_{t}$ & 0.191 & 1.977 & -0.753 & 0.164 & 1.055 \\
$d_{t}$ & 0.788 & 0.762 & 0.342 & 0.653 & 1.019 \\
M/B ratio & 2.863 & 3.154 & 1.598 & 2.173 & 3.123 \\
\hline
\end{tabular}

Note: All variables are based on per share except for ratios. $P_{t}$ is market value of common equity at the end of year $t . B V_{t}$ is book value of common equity at the end of year $t . N I_{t}$ is net income. $R I_{t}\left(R I F_{t}\right)$ is residual income, calculated as $R I_{t}=N I_{t}-r B V_{t-1}$, where $\mathrm{r}$ is the constant (floating) capital cost. $d_{t}$ is common dividends. M/B is the market-to-book ratio. 
Table 3

Correlation between Dependent and Independent Variables

\begin{tabular}{cllllllll}
\hline Variable & \multicolumn{1}{c}{$\mathrm{P}$} & $\mathrm{BV}$ & $\mathrm{NI}$ & $\mathrm{d}$ & $\mathrm{r}$ & $\mathrm{RI}$ & $\mathrm{RIF}$ & $\mathrm{M} / \mathrm{B}$ \\
\hline $\mathrm{P}$ & 1 & 0.762 & 0.558 & 0.488 & 0.030 & 0.042 & 0.410 & 0.132 \\
$\mathrm{BV}$ & 0.684 & 1 & 0.541 & 0.492 & 0.029 & -0.086 & 0.321 & -0.151 \\
$\mathrm{NI}$ & 0.692 & 0.597 & 1 & 0.341 & 0.013 & 0.102 & 0.969 & 0.007 \\
$\mathrm{~d}$ & 0.650 & 0.693 & 0.587 & 1 & 0.007 & 0.005 & 0.232 & -0.049 \\
$\mathrm{r}$ & 0.101 & -0.036 & 0.062 & -0.029 & 1 & -0.354 & 0.008 & 0.010 \\
$\mathrm{RI}$ & 0.151 & 0.058 & 0.385 & 0.149 & -0.704 & 1 & 0.137 & 0.014 \\
$\mathrm{RIF}$ & 0.583 & 0.367 & 0.937 & 0.457 & 0.087 & 0.434 & 1 & 0.049 \\
$\mathrm{M} / \mathrm{B}$ & 0.281 & -0.431 & 0.055 & -0.130 & 0.185 & 0.099 & 0.224 & 1 \\
\hline
\end{tabular}

Note: Pearson (Spearman) correlations are above (below) the diagonal.

Table 4

Panel Cointegration Tests

Panel A. Least-squares dummy variable based cointegration tests

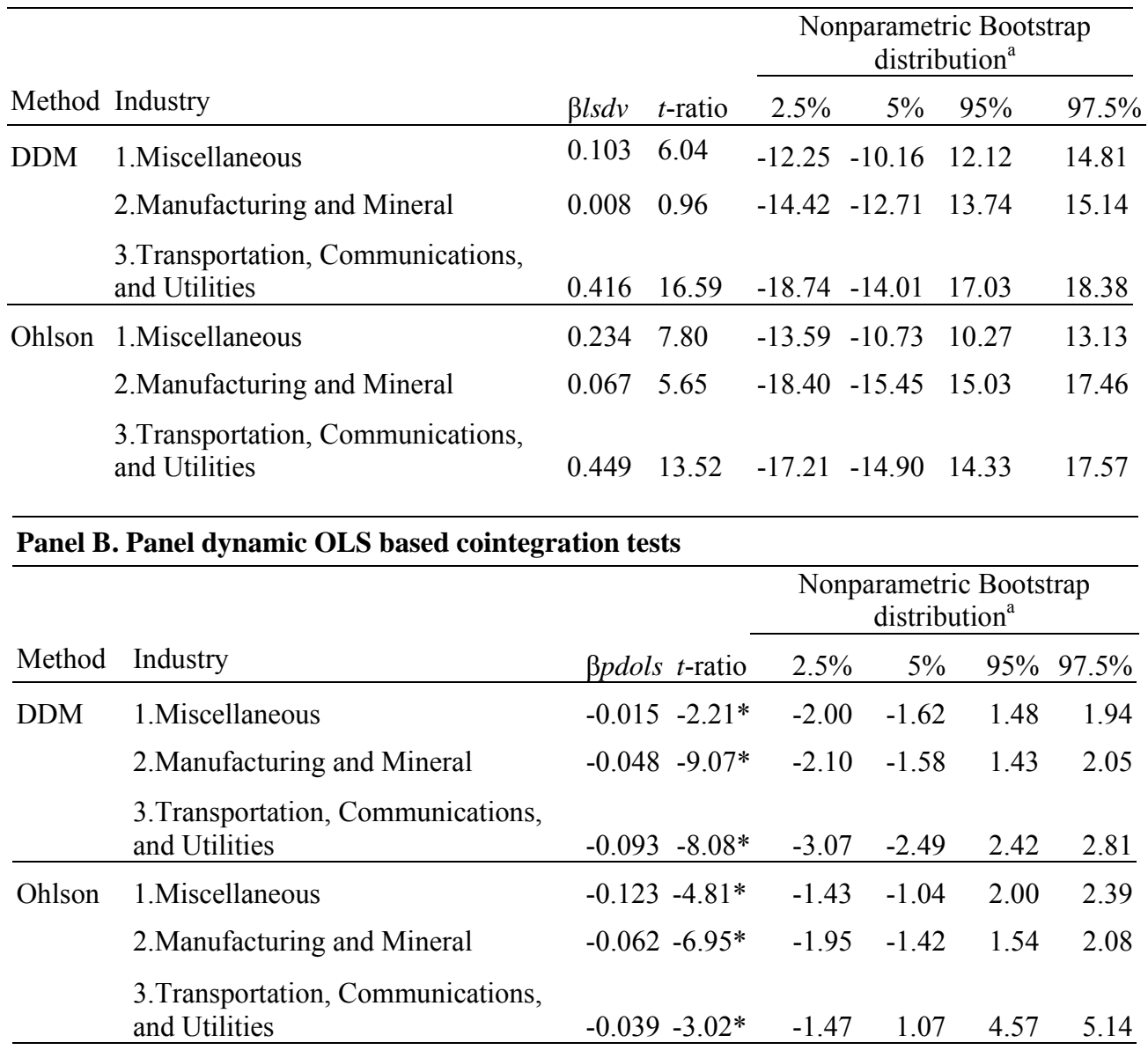

Note: a. Null hypothesis: No cointegration.

$*$ Significant at $\alpha=0.05$. 


\subsection{Tests for Panel Cointegration of Models}

We consider three alternative industries. The three industries are (i) miscellaneous industries; (ii) manufacturing and mineral industries; and (iii) transportation, communications, and utilities. We employ least-squares dummy variable (LSDV) test and Mark and Sul (2001) panel cointegrating test; and the results of the panel test for cointegration are reported in Table 4.

In Table 4, Panel A and B present the results of LSDV test and Mark and Sul (2001) panel cointegration test, respectively. Under the LSDV test, we find that the null hypothesis of no cointegration is not rejected by all of the three industries at $\alpha=0.05$ in the dividend discount model and in the Ohlson (1995) model. Under the Mark and Sul (2001) panel cointegration test, the findings presented in the dividend discount model show that the null hypothesis of no cointegration is rejected by all of the three industries at $\alpha=0.05$. These results imply that the existence of a long-run equilibrium relationship between stock price and dividend. Meanwhile, the findings presented in the Ohlson (1995) model also showed that the null hypothesis of no cointegration is rejected by all of the three industries at $\alpha=0.05$. This result implies that the book values of equity and residual income are important variables for the understanding of stock price in the long run.

In summary, under the Mark and Sul (2001) panel cointegration test, we reject the hypothesis of no cointegration between the stock price and dividend. We also reject the hypothesis of no cointegration between the stock price and key accounting variables in the Ohlson (1995) model. The strength of the evidence for the dividend discount model and the Ohlson (1995) model is roughly equivalent.

\subsection{Tests for Out-of-sample Prediction}

We generate out-of-sample forecasts at 1-year horizon, 2-year horizon, 3-year horizon and 4year horizon. For 1-year horizon, we use in-sample data from 1986-2003 to predict 2004; for 2-year horizon, we use in-sample data from 1986-2002 to predict the period 2003-2004; for 3-year horizon, we use in-sample data from 1986-2001 to predict the period 2002-2004; for 4-year horizon, we use in-sample data from 1986-2000 to predict the period 2001-2004. The Theil's $U$-statistic is used to measure relative forecast accuracy of the Ohlson (1995) model and the dividend discount model. The paired $t$ and Wilcoxon signed rank tests are also employed to examine whether significant difference in the Theil's $U$-statistic exists from two competing models.

Panels A and B of Table 5 report the prediction results for the Theil's $U$-statistic of two competing models at 1-year horizon. The mean (median) Theil's $U$-statistic is smaller for the Ohlson (1995) model than that for the dividend discount model in Miscellaneous industry. The hypothesis that the Ohlson (1995) model provides superior forecast power is not rejected in Miscellaneous industry as well as in Transportation, Communications, and Utilities industries. Panels $\mathrm{C}$ and $\mathrm{D}$ show the prediction results for the two competing models at 2-year horizon. Again, the hypothesis that the Ohlson (1995) model performs better is not rejected in Miscellaneous industry as well as in Transportation, Communications, and Utilities industries.

Panels $\mathrm{E}$ and $\mathrm{F}$ show the prediction results for 3-year horizon. The null hypothesis of the Ohlson (1995) model forecasts outperform the dividend discount model can be rejected only for manufacturing and mineral industry. Panels $\mathrm{G}$ and $\mathrm{H}$ report the results for 4-year horizon. The mean (median) Theil's $U$-statistic is smaller for the Ohlson model than that for the dividend discount model in two industries. Also, the hypothesis that the Ohlson (1995) model provides superior forecast power cannot be rejected for all industries at $\alpha=0.05$. 
Table 5

Out-of-Sample Forecasts of the DDM and the Ohlson Model

\begin{tabular}{|c|c|c|c|}
\hline \multicolumn{4}{|c|}{ Panel A. One-year forecasts: Theil's U statistic } \\
\hline \multirow[b]{2}{*}{ Fundamentals } & \multirow{2}{*}{ 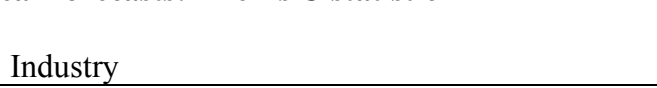 } & \multicolumn{2}{|c|}{ Theil's $U$ statistic } \\
\hline & & Mean & Median \\
\hline \multirow[t]{3}{*}{ DDM } & 1.Miscellaneous $(\mathrm{N}=60)$ & 1.046 & 1.029 \\
\hline & 2.Manufacturing and Mineral $(\mathrm{N}=228)$ & 0.854 & 0.827 \\
\hline & $\begin{array}{l}\text { 3.Transportation, Communications, and Utilities } \\
(\mathrm{N}=92)\end{array}$ & 0.793 & 0.741 \\
\hline \multirow[t]{3}{*}{ Ohlson } & 1.Miscellaneous $(\mathrm{N}=60)$ & 0.591 & 0.507 \\
\hline & 2.Manufacturing and Mineral $(\mathrm{N}=228)$ & 0.883 & 0.861 \\
\hline & $\begin{array}{l}\text { 3.Transportation, Communications, and Utilities } \\
(\mathrm{N}=92)\end{array}$ & 0.796 & 0.734 \\
\hline \multirow{3}{*}{\multicolumn{4}{|c|}{$\begin{array}{l}\text { Panel B. One-year forecasts: Paired t test (mean) and Wilcoxon signed rank test (median) } \\
\qquad \begin{array}{l}H_{0}: U_{D D M} \geq U_{O h l s o n} \\
H_{1}: U_{D D M}<U_{O h l s o n}\end{array}\end{array}$}} \\
\hline & & & \\
\hline & & & \\
\hline \multicolumn{2}{|l|}{ Industry } & $\begin{array}{l}\text { Paired } \\
\text { t-value }\end{array}$ & $\begin{array}{r}\text { Wilcoxon } \\
\text { z-value }\end{array}$ \\
\hline \multicolumn{2}{|c|}{ 1.Miscellaneous } & 20.974 & 6.736 \\
\hline \multicolumn{2}{|c|}{ 2.Manufacturing and Mineral } & $-6.580^{*}$ & $-6.348^{*}$ \\
\hline \multicolumn{2}{|c|}{ 3.Transportation, Communications, and Utilities } & -0.498 & -0.938 \\
\hline
\end{tabular}

Panel C. Two-year forecasts: Theil's $\boldsymbol{U}$ statistic

\begin{tabular}{llcc} 
& & \multicolumn{2}{c}{ Theil's $U$ statistic } \\
\cline { 2 - 4 } Fundamentals & Industry & Mean & Median \\
\hline DDM & 1.Miscellaneous $(\mathrm{N}=60)$ & 1.978 & 1.876 \\
& 2.Manufacturing and Mineral $(\mathrm{N}=228)$ & 1.841 & 1.726 \\
& 3.Transportation, Communications, and Utilities & 1.663 & 1.306 \\
& $(\mathrm{~N}=92)$ & & \\
\hline Ohlson & 1.Miscellaneous $(\mathrm{N}=60)$ & 1.825 & 1.784 \\
& 2.Manufacturing and Mineral $(\mathrm{N}=228)$ & 1.866 & 1.736 \\
& 3.Transportation, Communications, and Utilities & 1.629 & 1.294 \\
& & & \\
\hline
\end{tabular}

Panel D. Two-year forecasts: Paired t test (mean) and Wilcoxon signed rank test (median)

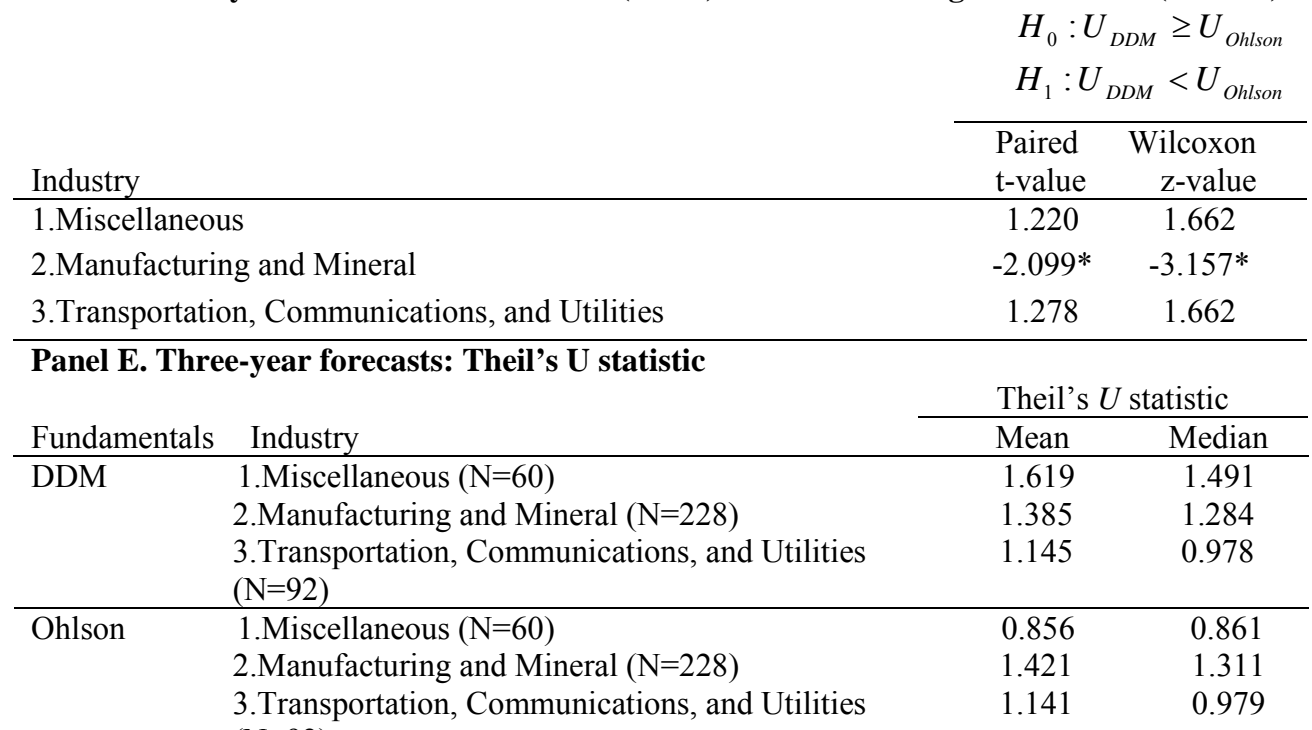
$(\mathrm{N}=92)$ 


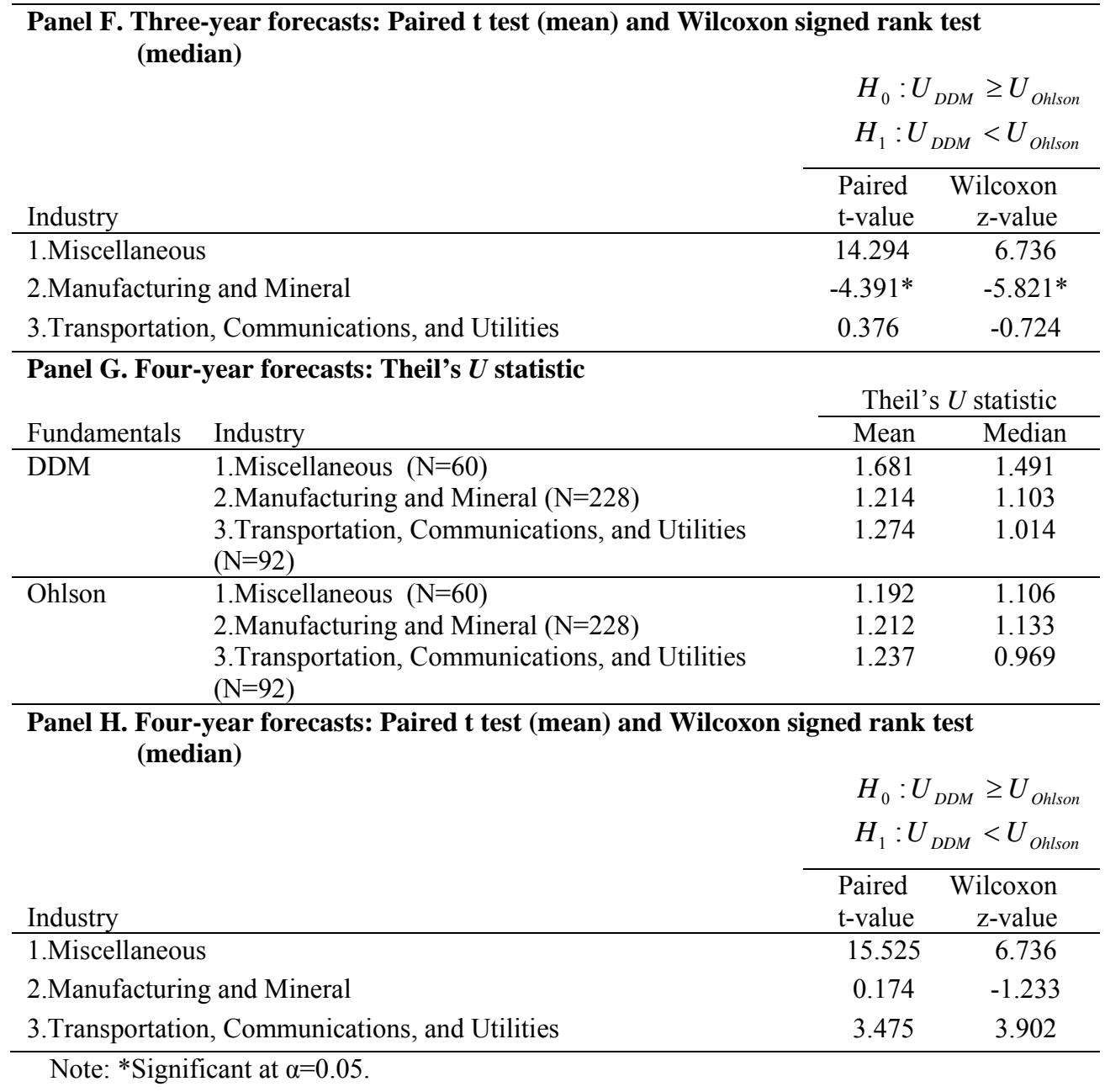

In summary, we find that the Ohlson model provides better predictive ability for future stock price movements in most predict horizon. Furthermore, our evidence suggests that the linkage between the stock price and fundamental value of corporations in the Ohlson model is tighter than that linkage in the dividend discount model.

\section{Conclusions}

This paper investigates whether accounting variables will cointegrate with the market value of equity in the dividend discount model and the Ohlson model through panel cointegration. It also examines whether equity fundamental value can forecast future stock price movements. According to the panel cointegration tests, we reject not only the hypothesis of no cointegration between the stock price and dividend, but also the hypothesis of no cointegration between the stock price and key accounting variables in the Ohlson model. Thus, a long-run equilibrium relationship between stock price and the fundamental value of corporations exists in the dividend discount model and the Ohlson model.

We also find that, at different predict horizon, the Ohlson model has better ability to predict future stock price. The following reasons may explain why dividend discount model has poor forecast performance: (i) Many firms such as high-tech and high-growth firms, do not pay regular cash dividends until much later in their life cycle; (ii) The conventional 
dividend discount model tends to use narrow cash dividends and ignores the potentially important role of share repurchase; (iii) The narrow cash dividends provide insufficient information on future firm profit.

\section{References}

Abarbanell, J \& Bernard, V 2000, 'Is the U.S. stock market myopic?', Journal of Accounting Research, vol. 38, pp221-242. http://dx.doi.org/10.2307/2672932

Ahmed, A, Morton, R \& Schaefer, T 2000, 'Accounting conservatism and the valuation of accounting numbers: Evidence on the Feltham-Ohlson (1996) model', Journal of Accounting, Auditing and Finance, vol. 15, pp271-292.

Ballester, M, Livnat, J \& Sinha, N 2002, 'Labor costs and investments in human capital', Journal of Accounting, Auditing and Finance, vol. 17, pp351-373.

Berben, R \& van Dijk, D 1998, 'Does the absence of cointegration explain the typical findings in long horizon regressions?', Econometrics Institute. Erasmus University Rotterdam, Report 9814.

Callen, J \& Morel, M 2000, 'A Lintnerian linear accounting valuation model, Journal of Accounting, Auditing and Finance, vol. 15, pp301-314.

Callen, J \& Morel, M 2005, 'The valuation relevance of R\&D expenditures: Time series evidence', International Review of Financial Analysis, vol. 14, pp304-325. http://dx.doi.org/10.1016/j.irfa.2004.10.007

Campbell, J \& Shiller, R 1988, 'Stock price, earnings and expected dividends', Journal of Finance, vol. 43, pp661-676. http://dx.doi.org/10.1111/j.1540-6261.1988.tb04598.x

Chava, S \& Jarrow, R 2004, 'Bankruptcy prediction with industry effects', Review of Finance, vol. 8, pp537-569. http://dx.doi.org/10.1093/rof/8.4.537

Dechow, P, Hutton, A \& Sloan, R 1999, 'An empirical assessment of the residual income valuation model', Journal of Accounting and Economics, vol. 26, pp1-34. http://dx.doi.org/10.1016/S0165-4101(98)00049-4

Engle, R \& Granger, C 1987, 'Co-integration and error correction: Representation, estimation, and testing', Econometrica, vol. 55, pp251-276. http://dx.doi.org/10.2307/1913236

Fama, E \& French, K 1988, 'Dividend yields and expected stock returns', Journal of Financial Economics, vol. 22, pp3-25. http://dx.doi.org/10.1016/0304-405X(88)90020-7

Fama, E \& French, K 1992, 'The cross-section of expected stock returns', Journal of Finance, vol. 47, pp427-465. http://dx.doi.org/10.1111/j.1540-6261.1992.tb04398.x

Francis, J, Olsson, P \& Oswald, D 2000, 'Comparing the accuracy and explainability of dividends, free cash flow, and abnormal earnings equity valuation', Journal of Accounting Research, vol. 38, pp45-70. http://dx.doi.org/10.2307/2672922

Frankel, R \& Lee, C 1998, 'Accounting valuation market expectation and cross-sectional stock returns', Journal of Accounting and Economics, vol. 25, pp283-319. http://dx.doi.org/10.1016/S0165-4101(98)00026-3

Granger, C \& Newbold, P 1974, 'Spurious regressions in Econometrics', Journal of Econometrics, Vol 2, pp111-120. http://dx.doi.org/10.1016/0304-4076(74)90034-7

Hansen, B 1995, 'Rethinking the univariate approach to unit root testing: Using covariates to increase power', Econometric Theory, vol. 11, pp1148-1171. http://dx.doi.org/10.1017/S0266466600009993

Hodrick, R 1992, 'Dividend yields and expected stock returns: Alternative procedures for inference and measurement', Review of Financial Studies, vol. 5, pp357-386. http://dx.doi.org/10.1093/rfs/5.3.357 
Karathanassis, G 2003, 'An empirical investigation of the traditional and the clean surplus valuation models', Managerial Finance, vol. 29, pp55-66. http://dx.doi.org/10.1108/03074350310768472

Lee, C, Myers, J \& Swaminathan, B 1999, 'What is the intrinsic value of the Dow?', Journal of Finance, vol. 54, pp1693-1741. http://dx.doi.org/10.1111/0022-1082.00164

Lo, K \& Lys, T 2000, 'The Ohlson model: Contribution to valuation theory, limitations, and empirical applications', Journal of Accounting, Auditing and Finance, vol. 3, pp147161.

Mark, N \& Sul, D 1999, 'A computationally simple cointegration vector estimator for panel data', Mimeo., Ohio State University. http://dx.doi.org/10.1016/S0022-1996(00)00052-0

Mark, N \& Sul, D 2001, 'Nominal exchange rates and monetary fundamentals evidence from a small post-Bretton woods panel', Journal of International Economics, vol. 53, pp2952.

Morel, M 1999, 'Multi-lagged specification of the Ohlson model', Journal of Accounting, Auditing and Finance, vol. 14, pp147-161.

Morel, M 2003, 'Endogenous parameter time series estimation of the Ohlson model: Linear and nonlinear analyses', Journal of Business Finance \& Accounting, vol. 30, pp13411362. http://dx.doi.org/10.1111/j.0306-686X.2003.05444.x

Myers, J 1999, 'Implementing residual income valuation with linear information dynamics', The Accounting Review, vol. 74, pp1-28. http://dx.doi.org/10.2308/accr.1999.74.1.1

Ohlson, J 1995, 'Earnings, book values, and dividends in equity valuation', Contemporary Accounting Research, vol. 11, pp661-687. http://dx.doi.org/10.1111/j.19113846.1995.tb00461.x

Penman, S \& Sougiannis, T 1998, 'A comparison of dividend, cash flow, and earnings approaches to equity valuation', Contemporary Accounting Research, vol. 15, pp343383. http://dx.doi.org/10.1111/j.1911-3846.1998.tb00564.x

Phillips, P 1986, 'Understanding spurious regressions in econometrics', Journal of Econometrics, vol. 33, pp311-340. http://dx.doi.org/10.1016/0304-4076(86)90001-1

Phillips, P \& Perron, P 1988, 'Testing for a unit root in time-series regression', Biometrica, vol. 75, pp335-346. http://dx.doi.org/10.1093/biomet/75.2.335

Qi, D, Wu, Y \& Xiang, B 2000, 'Stationarity and cointegration tests of the Ohlson model', Journal of Accounting, Auditing and Finance, vol. 2, pp141-160.

$\mathrm{Wu}, \mathrm{C}, \mathrm{Kao}, \mathrm{W} \&$ Lee, C 1996, 'Time-series properties of financial series and implications for modeling', Journal of Accounting, Auditing and Finance, vol. 11, pp277-303. 